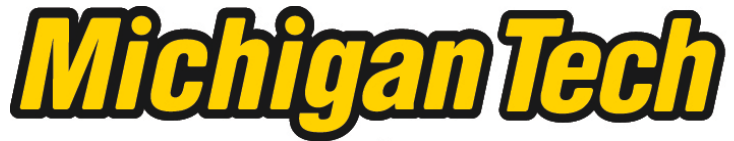 \\ Michigan Technological University Create the Future Digital Commons @ Michigan Tech
}

\section{Locating American Indian Sciences : a report on the development, use, and analysis of a survey of perceptions}

John Eric Holmlund

Michigan Technological University

Follow this and additional works at: https://digitalcommons.mtu.edu/etds

Part of the Rhetoric and Composition Commons

Copyright 2011 John Eric Holmlund

\section{Recommended Citation}

Holmlund, John Eric, "Locating American Indian Sciences : a report on the development, use, and analysis of a survey of perceptions", Master's report, Michigan Technological University, 2011.

https://doi.org/10.37099/mtu.dc.etds/545

Follow this and additional works at: https://digitalcommons.mtu.edu/etds

Part of the Rhetoric and Composition Commons 
LOCATING AMERICAN INDIAN SCIENCES: A REPORT ON THE DEVELOPMENT, USE, AND ANALYSIS OF A SURVEY OF PERCEPTIONS

\author{
By \\ John Eric Holmlund \\ A REPORT \\ Submitted in partial fulfillment of the requirements for the degree of \\ MASTER OF SCIENCE \\ RHETORIC AND TECHNICAL COMMUNICATION
}

MICHIGAN TECHNOLOGICAL UNIVERSITY

2011

(C) 2011 John Eric Holmlund 
This report, "Locating American Indian Sciences: A Report on the Development, Use, and Analysis of a Survey of Perceptions," is hereby approved in partial fulfillment of the requirements for the Degree of MASTER OF SCIENCE IN RHETORIC AND TECHNICAL COMMUNICATION.

\author{
Department of Humanities
}

Signatures:

\begin{tabular}{ll} 
Report Co-Advisor & \\
\cline { 2 - 2 } Dr. Craig Waddell \\
Report Co-Advisor & \\
\cline { 2 - 2 } & \\
Department Chair & \\
\cline { 2 - 2 } & Dr. Ronald Strickland
\end{tabular}

Dr. Ronald Strickland

Date 


\begin{abstract}
All students in the United States of America are required to take science. But what if there is not a science, but in fact a number of sciences? Could every culture, perhaps every different grouping of people, create its own science? This report describes a preliminary survey, the goal of which is to improve the teaching of science at American Indian Opportunities and Industrialization Center in Minneapolis, Minnesota by beginning to understand the differences between Western and American Indian sciences.
\end{abstract}




\section{Table of Contents}

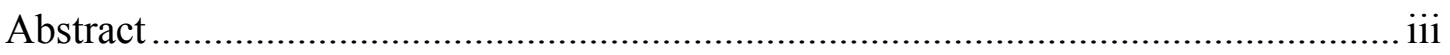

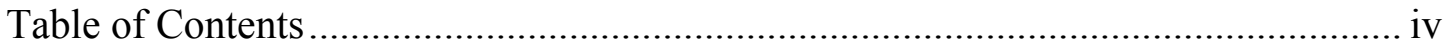

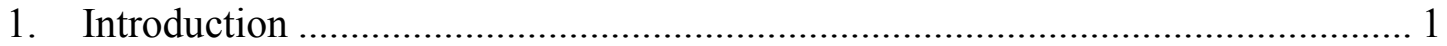

2. How I Came To Do A Survey ..................................................................... 2

2.1 Coursework at Michigan Technological University .......................................... 2

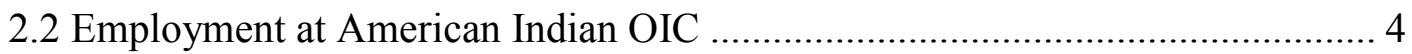

2.3 The American Indian Science(s) Project and the American Indian Science

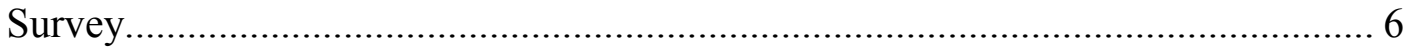

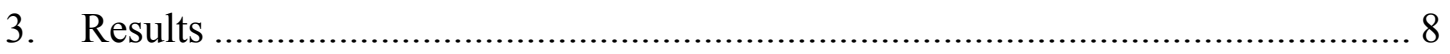

3.1 Format of the Survey Instrument …………….............................................. 8

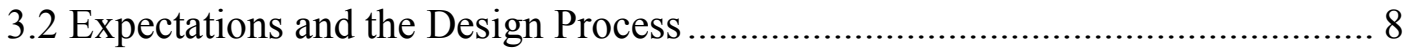

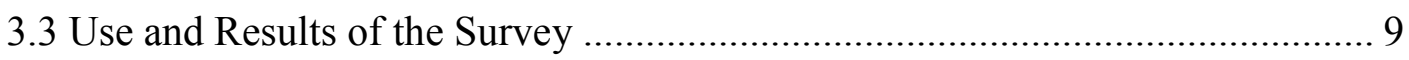

4. Defining Western Science(s) and American Indian Science(s).......................... 11

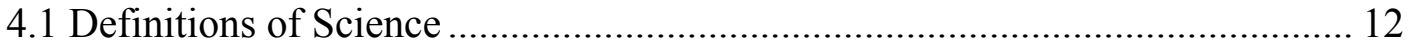

4.2 Toward Culturally Specific Definitions of Science ………………………...... 14

4.3 American Indian Sciences and Western sciences ............................................ 19

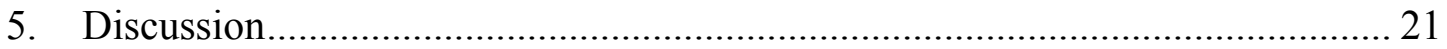

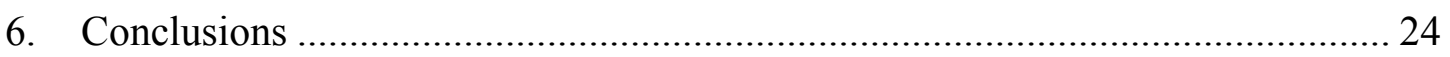

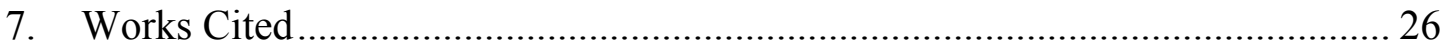

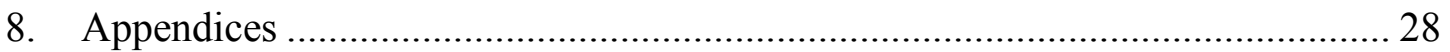

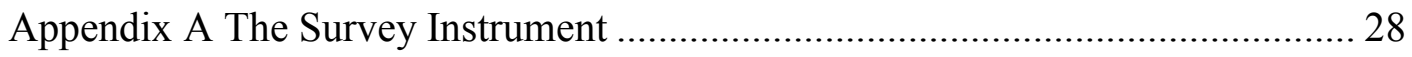

Appendix B Expectations of Results of AISS ........................................................... 33

Appendix C Table of Responses for Question 17 .................................................. 38 


\section{Introduction}

Within my first year of teaching at American Indian Opportunities and Industrialization Center (AIOIC) in Minneapolis, Minnesota, I began to see that significant aspects of American Indian culture could be included in the science classes at AIOIC. In addition, I began to realize that there is and always has been a distinct American Indian science (or sciences, as discussed below). Since the Fall of 2008, I have assumed that American Indian science exists; consequently, I have made it explicit in all the science classes I have taught that one of our goals is to develop an understanding of American Indian science. This approach appears to have improved student attitudes toward science and, consequently, their attitudes toward learning. When I developed a survey of the adult students and community members of AIOIC as a project for my master's degree, I took this as an opportunity to improve the teaching of sciences at AIOIC by trying to understand the differences between Western and American Indian sciences.

In developing, using, and analyzing my American Indian Science Survey (AISS), I have gained an understanding of practicalities of field research. At the same time, I have developed a clearer definition of what I originally set out to find by using a survey. This report includes a discussion of (1) how I decided to do a survey, (2) the survey design and administration, (3) what I mean by "American Indian sciences," and (4) research methods that might be more suitable for defining American Indian sciences. 


\section{How I Came To Do A Survey}

\subsection{Coursework at Michigan Technological University}

When I first began my master's degree, I intended to study the role of rhetoric in paradigm shifts. I had completed a baccalaureate degree in physics in 2001 and certification in secondary education in physics and mathematics in 2002. During this time, I had become interested in how science changes over time. For example, what I learned about physics during my undergraduate years (1995-2002) might now be considered history since it is not necessarily physics as it is presently understood. I learned that both knowledge and method change over time and that it is difficult to predict these changes. I also learned that what gets researched depends on funding, which depends on the interest and will of society. This societal involvement in science suggests that rhetoric plays a significant role in changes in science, particularly in the Kuhnian paradigm shifts I had read about as an undergraduate (Kuhn 1-9). While I was most interested in paradigm shifts, I also suspected that rhetoric was involved in other aspects of science.

When I enrolled in the Master's Program in Rhetoric and Technical Communication in the Fall of 2003, I found myself immersed in rhetoric, philosophy, and critical perspectives of science and technology. I also had my first explicit experiences with many theoretical concepts, including culture, feminism, inequality, agency, and voice. After completing the core courses, I took elective courses, including Technology, Culture \& Communication; History \& Theory of Rhetoric; Critical Perspectives on 
Science \& Technology; Linguistic Analysis; and Backgrounds of Critical Theory. Each of these courses presented a different perspective and different methods of approaching the problem that I had set out to understand — and all of these approaches seemed valid.

Unfortunately, no graduate-level class was offered in rhetoric of science, which provides a framework for understanding the relationship between these two disciplines. In his book Rhetoric of Science, Alan Gross lays out one of the defining moments in science in a chapter on the difference between two of Newton's papers on optics (111128). Gross explains that although the knowledge Newton was trying to convey in the two papers was the same, the method Newton used to convey that knowledge in these two papers was rhetorically distinct. According to Gross, that change in rhetoric also created a change in scientific method (126). If Gross in right, then, clearly, rhetoric plays a significant role in defining science.

Herbert W. Simons writes, "other cultures' systems of thought may be every bit as coherent as our own and no less functional for them, it is but a short step back to the conclusion that there are multiple rationalities" (13). He continues, "a good case can indeed be made that reason is inherently rhetorical" (13). Although, Simons provides no method of choosing between different theories (or paradigms), he argues that rhetoric would always be part of any such method (14-22). These ideas-that other systems of thought are as coherent as our own, that reason is rhetorical, and that it is difficult to choose between two paradigms - suggest that rhetoric is an essential component of science. 
Ultimately, I found my initial interests in rhetoric and technical communication to be too broad for a master's project; nevertheless, these interests have had a profound impact on how I view the world. The Rhetoric and Technical Communication program also gave me the tools I needed to continue my academic development even while employed.

\subsection{Employment at American Indian OIC}

After completing my RTC coursework, I had the opportunity to work at AIOIC. AIOIC was formed in 1979 as a job-placement facility as a part of the international Opportunities and Industrialization Centers (OIC) movement, which was initiated by members of the African-American community in the 1960s. Within its first few years of operation, AIOIC came to include the School of Business and Office Technology (SOBOT), a post-secondary institution accredited through what is now the North Central Association Commission on Accreditation and School Improvement (NCA CASI). AIOIC has grown to include adult basic education as preparation for the general equivalency exam (ABE-GED) and the Career Immersion High School (CIHS), a contract alternative school in the Minneapolis Public School system. My responsibilities have included working in all three programs.

Initially, the primary focus of my work at AIOIC was the CIHS. One of my goals was developing a curriculum inclusive of American Indian cultures. This continues to be a goal of mine, in part because of the lack of culturally inclusive resources and texts available for use, especially in mathematics and science. Immediately after I was hired, I 
began collecting articles (typically news reports) and texts (typically academic) relevant to high-school science and mathematics; this work continues to this day. Within the confines of the Minnesota State Standards, I have been able to fit into the curriculum an occasional article of science news regarding or relevant to American Indians. Resources and texts regarding American Indians and mathematics have been more difficult to come by, but I have had some successes.

As part of its outreach programs, the Science Museum of Minnesota (SMM) holds an annual "American Indians in Science" event. The most recent event was held in January of 2011. After reflecting on my various experiences at SMM-including attendance at two "American Indians in Science" events, personal visits to the museum, use of the SMM's Science House, and participation in SMM's ethnobotany project-I started to see a significant difference between the Science Museum's “American Indians in Science" event and American Indian Science(s). First, the use of the preposition in makes American Indians outsiders to science and the scientific community; second, observations and concepts of American Indians that fall outside of traditional, Western definitions of science but that might, nonetheless, be considered scientific are invalidated by the "American Indians in [Western] Science" model.

Since I first began working at AIOIC, my responsibilities have grown to include aspects of the accreditation of SOBOT. To offer financial aid to students in SOBOT, AIOIC must be accredited. All NCA-CASI-accredited schools go through a continuousimprovement process that includes an evaluation and site visit every five years. Prior to 
the most recent site visit, the SOBOT Steering Committee determined that assessment of reading and math would be two of the main goals for the current evaluation period.

In spring of 2010, in the midst of preparations for the NCA CASI site visit, AIOIC was approved for a federal grant to expand SOBOT offerings in health occupations, including the addition of a Practical Nurse (PN) program, which would require a course in anatomy and physiology. Previously, mathematics had been the most difficult subject for AIOIC students; now, however, I believed that AIOIC was entering an era where science might be the most difficult subject.

\subsection{The American Indian Science(s) Project and the American Indian Science Survey}

Building on work that has already been done at the CIHS, this project will identify some of the major differences between Western scientific paradigms and American Indian scientific paradigms. This will have the following six advantages: (1) it will enable greater exploration of American Indian science(s) and American Indian culture(s) at AIOIC; (2) it will help raise American Indian sciences to their rightful status alongside Western sciences; (3) it will help scientists of both cultures bridge the gap between the two cultures in the further advancement of science; (4) it will preserve the distinction between Western sciences and American Indian sciences; (5) it will enable the exploration of American Indian science as a culture of its own; and (6) it will add to the growing body of scholarship on American Indians sciences. 
I did not intend to complete this larger American Indian Sciences project during my master's project; instead, I intended that the larger project would extend until the end of the current accreditation period of the AIOIC School of Business and Office Technology (spring 2015). However, my master's project does take the first steps toward the larger project; specifically, it is a pilot project to determine the suitability of using a survey to begin identifying some of the major differences between Western scientific paradigms and American Indian scientific paradigms. The American Indian Science Survey (AISS) that I have developed is intended to be used by AIOIC as part of its continuous-improvement process to better understand the AIOIC students and community, to inform teaching practice at AIOIC, and to develop culturally inclusive curricula in science. 


\section{Results}

\subsection{Format of the Survey Instrument}

The American Indian Science Survey (AISS) that I designed for this project was printed as a four-page booklet on a single sheet of eleven-by-seventeen-inch paper. This provided a clear way to distinguish between information collected from American Indian students and information collected from students not identifying as American Indian. Everyone who took the AISS completed the front and back pages (questions 1-7, and 1422). Participants who identified themselves as American Indian also completed the two center pages (questions 8-13). See Appendix A.

\subsection{Expectations and the Design Process}

The survey instrument had to fulfill a number of roles. It had to be for all students, but it also had to include questions specificly for American Indian students. It had to include questions about science, learning, and school in general. It had to collect demographic information in a way that would allow distinctions to be made between different groups participating in the survey.

To avoid questions that might be offensive or confusing, I pre-tested potential survey questions in one-on-one interviews with four, fellow AIOIC staff members and in one group interview with four SMM staff members. Additionally—as a means of limiting biases - prior to analyzing the survey results, I articulated and examined my expectations for each of the survey questions. See Appendix B. 


\subsection{Use and Results of the Survey}

In October of 2010, while I was finalizing the survey instrument, the AIOIC administration was reorganized. Shortly thereafter, the AIOIC administration decided that the AISS would no longer be an AIOIC project. Nevertheless, AIOIC allowed me to conduct the survey, but not during intake and only at the discretion of instructors, either during or between classes. Fortunately, AIOIC holds occasional feasts for students and staff, and because a Thanksgiving feast was planned for November of 2010, I requested and received permission to conduct the survey then.

Four major demographic groups are identified by the AISS: American Indian students of AIOIC, American Indian non-students, non-American Indian students of AIOIC, and non-American Indian non-students. Of the 90 AISS participants, 34 were American Indian students, 20 were American Indian non-students, 19 were nonAmerican Indian students, and 9 were non-American Indian non-students. One nonAmerican Indian participant did not check either box to indicate whether he or she was a student or non-student, and seven American Indian participants did the same. These four groups can be further divided by gender. Of the 90 participants, 57 entered a response suggesting that they were female, 25 entered a response suggesting that they were male, and 8 entered nothing that would indicate their gender.

One of the most obvious issues with the survey was Question 6: schooling you have attended. Some respondents indicated that they had attended high school but did not indicate that they had attended either grade school or middle school; other respondents 
indicated that they had attended college or other post-secondary schools but did not indicate that they had attended $\mathrm{K}-12$.

The range for Question 8 (skills taught in a traditional setting or manner) was zero to 26. Out of all American Indian participants, the average number of boxes checked for this question was six. These participants typically listed one of their grandparents, parents, or an elder as the person who taught them the skill indicated.

Question 17 was "When you hear the word science, what kind of people do you imagine doing science (who are scientists), and what do you imagine them doing (what is science)? All legible responses to this question are listed (with misspellings) in the table in Appendix C.

I have not attempted any further use of the AISS, and the survey is not currently considered a part of the accreditation of SOBOT. 


\section{Defining Western Science(s) and American Indian Science(s)}

It is dangerous to use tools of oppression when trying to develop tools of liberation. According to Keoke and Porterfield, "Throughout history those who hold power have used it to create definitions that marginalize people who do not hold power. At the same time that they have made use of the technologies and resources of those they dominate, they have minimized them or failed to acknowledge their originators" (xi). The Oxford English Dictionary (OED) is renowned for its carefully written definitions and carefully researched word histories; nevertheless, the OED is not above criticism.

As historically and fundamentally oral cultures, American Indian concepts are particularly vulnerable to manipulation by a record of written language. As Weatherford shows, some words that are originally American Indian have been attributed to others (195-213). Perhaps the clearest example of this is the word honk, which Weatherford points out is likely a borrowed form of honck, which "is the Narraganset or Wampanoag word for Canada goose" (208), but which—-twenty years after Weatherford published this criticism — the OED still attributes to Henry David Thoreau. The OED's etymology maize attributes the first written use of the word to Christopher Columbus, which is understandable given the priority and primacy given to written language. Nevertheless, this illustrates how the OED is incomplete and, potentially, oppressive.

According to Smith, "Research, like schooling, once the tool of the colonization and oppression, is very gradually coming to be seen as a potential means to reclaim languages, histories, and knowledge, to find solutions to the negative impacts of colonialism and to give voice to an alternative way of knowing and of being" (91). This 
is certainly the goal of my research. The question would then be how to make this possible. An answer is suggested by Ringney, who writes, "Indigenous people now want research and its designs to contribute to the self-determination and liberation struggles as defined and controlled by their communities" (109-10). The following is an attempt to define science in a way that accomplishes that which Smith and Ringney suggest.

In the failings of my survey, I find myself compelled to better understand that which I set out to locate. According to Denzin and Lincoln, "There is a pressing need to show how the practices of qualitative research can help change the world in positive ways" (x). I don't believe that I can proceed without understanding what might, in this case, be positive.

\subsection{Definitions of Science}

Science is both concept and word, and while there is a large body of scholarship regarding the concept, it is sufficient here in trying to develop a definition of science to concern ourselves primarily with the word. The origins of science and science are Western, and it is therefore appropriate to look to the West for definitions and to begin to understand how (Western) science and science have spread to American Indian cultures. The earliest written use of the word science reported in the OED is from 1340 when the word was used to mean "the state or fact of knowing." According to the OED, by 1725, science had taken on its modern sense as "a branch of study which is concerned with a connected body of demonstrated truths or with observed facts systematically classified and more or less colligated by being brought under general laws, and which includes 
trustworthy methods for the discover of new truth within its own domain." Thus, science passed from a general way of knowing to a much more specific way of knowing, defined by its particular method.

While American Indians have few written, historical records of changes in their languages (like the OED), some now use the Internet as a means of preserving, expanding, and disseminating their languages. A comparison of historical records with online resources can provide the basis for an understanding of American Indian conceptions of science. Kolmeschate's online version of Bishop Frederic Baraga's Dictionary of the Otchipwe [Ojibwe] Language defines biziskenjigewin as "perfect knowledge, science" and gikendAsowin as "knowledge, science." In Baraga's original dictionary, science is defined as "kikendássowin; bisiskendjigewin." Williamson's An English-Dakota Dictionary lists both Wosdonye and Wooyspe for science. Wosdonye is also included as a definition for knowledge, learning, proficiency, and sense. Wooyspe is also listed as a definition for doctrine, education, instruction, lore, moral, normal, nurture, and tutelage.

The Lakota Language Consortium provides an online version of its New Lakota Dictionary, which returns "couldn't find 'science"” and then displays the synonym skill as wówayuphike, with a definition of "skill, art, cleverness, adroitness." These examples suggest that within some American Indian languages, science is perhaps meant to be something unobtainable, and in other American Indian languages, there appears to be no conception of science at all. The overall impression, however, is of general ways of 
knowing, comparable to the 1340 definition provided in the OED — not the specialized, 1725 definition.

One of the most accessible introductions to the idea of American Indian sciences is Gregory Cajete's Native Science. In his introduction, Cajete writes, "In Native languages there is no word for 'science,' nor for 'philosophy'. . . Native science is a metaphor for a wide range of tribal processes of perceiving, thinking, acting, and 'coming to know' that have evolved through human experience with the natural world" (2). Cajete continues, "When speaking about Indigenous or Native science, one is really talking about the entire edifice of Indigenous knowledge. Using the word 'science' is in many ways arbitrary, and it can be said to relate specifically to the ways in which people come to know something, or anything at all . . 'knowledge' and 'science' are used interchangeably among Indigenous scientists" (3-4). We see in Cajete the same pattern of generalization found in the examples given from Ojibwe, Dakota, and Lakota.

\subsection{Toward Culturally Specific Definitions of Science}

One danger in defining American Indian sciences as knowledge or philosophy is that anyone consciously or subconsciously thinking in terms of racist traditions of sociocultural evolution might conclude that American Indian sciences are primitive forms of science that have not had - and presumably never will have - the chance to develop into the "higher forms" of Western science. Implicit in theories of sociocultural evolution is the idea that Western science is the best, most-evolved form of science. This conception of science is reflected in the OED when science is defined as a branch of 
study. Peter Farb helps to move anthropology away from these misconceptions of how cultures evolve (9-14), but he does not completely avoid them (250). Harry Wolcott, writing in 2008, cannot avoid using quotes that contain racist language $(11,89,145,204)$, but he makes a point to apologize for his use of the words native, savage, and primitive (95-96). Academia may be moving away for the use of these and other racist terms, but their continued use in the media and by the general public demonstrates the need for a definition of American Indian sciences that would not suggest, to anyone, that these sciences are primitive.

Cajete argues that "Native science is most akin to what Western science calls environmental science or ecology" (4). This is also problematic because it diminishes American Indian sciences to one specialized area of knowledge. Ecology is one focus of American Indian sciences, but it is certainly not the only subject that American Indian sciences address. It is not possible to define American Indian sciences fully if we limit their scope at the outset.

Cajete says, "The Indigenous 'physicist' not only observes nature, but also participates in it with all his or her sensual being" (20). This idea that American Indian sciences can only be learned by participating in them is expanded upon by Aikenhead and Ogawa: "An Indigenous coming to know is a journey toward wisdom or a journey in wisdom-in-action, not a destination of discovering knowledge" (553). They continue, "Ways of living in nature is action-oriented (verb-based); it cannot be given, accumulated, banked, and assessed by paper and pencil examinations. It must be experienced in the context of living in a particular place in nature, in the pursuit of 
wisdom, and in the context of multiple relationships" (554). Aikenhead and Ogawa contend that American Indian sciences include both knowledge and method, just as Western sciences do. Another part of their argument is that American Indian sciences and Western sciences must be defined in terms of people. This can be better understood by examining the relationships between American Indian sciences and Western sciences on the one hand and self-determination and self-organization on the other.

American Indians have the right to self-determination, a right written into both international law (un.org) and the laws of the United States (uscode.house.gov). The OED definition (sense 2.) of self-determination is, "The action of a people in deciding its own form of government; free determination of statehood, postulated as a right."

A similar concept appropriate for describing science is self-organization. The OED includes self-organization as an entry for the prefix self-, including it as a "reflexive verbal phrase." Self-organization would therefore mean to organize oneself, and the OED defines (sense 2.c.) organize as, "To become coordinated, attain an orderly structure; spec. (of a political body, esp. a trade union) to form; to put in place an administrative structure; to plan organized action." Scientists have the ability to decide who will be a part of their group, what will be considered acceptable science, what results will be considered valid, what papers will be published, and what textbooks will be used. As Farb, writing in 1968, says, "All men everywhere exist as members of social groups, however small. A group of men is much more than a random collection of individuals who accidentally happen to share particular customs" (13). (Were he writing today, I 
assume that Farb would use more gender-neutral language.) In addition, everyone is a member of multiple groups, and many different groups are involved in science.

Self-organization is for science what self-determination is for American Indiansthe right to decide who you are. This includes the right to change. Change in both knowledge and method is what allows science, as a process of learning, to continue. Likewise, being able to change allows American Indians to bring historical aspects of their culture into practice and to develop something new and allow it to be a part of American Indian culture. What it means to be American Indian is, therefore, determined by who is an American Indian right now; similarly, what science is is determined by who is a scientist right now.

These parallels between self-determination and self-organization resolve two issues. First is the definition of American Indian sciences, which, quite simply, can be defined by their practitioners. Cajete writes, "Others perceive science as a way of understanding the world, a story of how things happen, a way that human beings have evolved to try and explain and understand existence in time and space and relationships vis-a-vis the natural processes of the world. In this perspective, every culture has science" (3). Hence, a close examination of other cultures may reveal other sciences. Mihesuah writes, "no one Indian voice exists; there are many points of view" (17). Therefore, the plural-American Indian sciences-is appropriate because there is no singular American Indian culture. There are many American Indian nations, hence, many American Indian sciences. For the same reason, even within Western societies, there may be more than one science. 
The other issue this way of defining science resolves is the problem of scientific practice changing over time. Western sciences, American Indian sciences, and American Indian nations have always been communities defined by the people who belong to them. We understand each of these communities by understanding the people who were involved in them at any given time.

Using the plural American Indian sciences helps to support the self-determination of American Indian nations. Minavavana's 1761 speech to the Englishman Alexander Henry identifies the French King as the father of his people, the Chippewa/Ojibwe (Blaisdell 16). Minavavana speaks of how the French respect his people with presents and treaties, and in spite of being at war with the English, he offers to regard Henry as a brother (17). Brother would have meant something different to Minavavana than it did to the English, and it is reasonable to assume that when talking to his own people, Minavavana would use the Chippewa/Ojibwe word for brother. However, Minavavana's use of the word brother in this speech would be as a sign of respect. Likewise, using the plural American Indian sciences is a way for the privileged to show their respect for American Indian nations.

The racist notions of sociocultural evolution suggest universal stages of evolution from primitive to modern. A definition of American Indian science(s) from this perspective might be "those aspects of American Indian cultures that parallel the knowledge and methods of Western science." Likewise, definitions of an American Indian philosophy, or way, or knowledge all risk falling prey to the same racist conceptions. Only a different conception of science will avoid this problem. 


\subsection{American Indian Sciences and Western sciences}

American Indian sciences are those aspects of American Indian cultures that enable the creation of solutions to the material problems of American Indian communities. Material in this case means observable, but it also means both matter and energy via their equivalence. This equivalence implies the inclusion of spirit, because, as Cajete has written, "what Native Americans refer to as 'spirit' and energy waves are the same thing" (x). This definition does not require validation by Western science. It supports the self-determination of American Indian nations because it implies that all cultures have science, even if they do not have a corresponding word for it. From this perspective, science is found everywhere; it is not unique to Western society.

Use of American Indian sciences and Western sciences raises the cultural activities of American Indian nations to their proper place as equal to those of Western nations. These phrases support broader recognition and acceptance of the idea that Western sciences should be used in place of a cultureless science. The plural forms suggest the possibility that-rather than being limited to ecology-American Indian sciences might include any of the many subfields/specializations included in Western sciences. These phrases also acknowledge the possibility that Western sciences might become more like American Indian sciences: sustainable, personal, and centered around the needs of community.

I do not presume that American Indian sciences will become the preferred phrase within the diverse American Indian communities: American Indian nations will certainly 
adopt terms of their choosing. Science has and will continue to be defined differently in each American Indian nation's language. Some may choose to consider the word profain. Others may deliberately choose not to define science at all as a way of undermining its privileged status. However, I offer the phrase American Indian sciences as a means for those who are privileged to support the self-determination of American Indian nations by identifying a cultural context within which all communities can be considered equals. 


\section{Discussion}

In examining the AISS in light of my definition of science, it is apparent that American Indians respondents have a body of scientific knowledge that they pass among from generation to generation. American Indian participants checked six boxes on average for Question 8 (skills taught in a traditional setting or manner). Although some know very little about their cultural heritage, the vast majority demonstrate varying degrees of knowledge of this heritage. What processes were involved in learning these skills? How experienced are the participants in these skills? Do they have the experience to be considered teachers of these skills? These and many other questions remain unanswered. Additionally — because of the limited number of completed surveys and because of inconsistencies with the surveys that were completed - there is little utility in the information gathered. Both the accuracy and amount of data need to be increased beyond the scope of what this survey accomplished.

These issues suggest that a more complete picture might be obtained by the use of ethnographic/qualitative research methods, which could help to illuminate not only what American Indians know about American Indian sciences but also how and why they know it. Mihesuah writes, "no one Indian voice exists; there are many points of view" (17). To value as many voices as possible, participants must have an opportunity to speak and be heard in a more open-ended way. As personal and learned through participation (as discussed above), American Indian sciences echo the warnings of Wolcott regarding the limitations of ethnography as "one person's view, at one point in time, based on one set of experiences, enhanced by a purposeful but serendipitous selections of experiences 
related by others" (80). A survey forces participants to break their experiences into pieces that fit the boxes provided; on the other hand, qualitative research methods allow the possibility of both seeing those experiences as connected by the participant and sharing in some of those experiences.

The three methods identified by Wolcott—participant observation, interviewing, and archival research (48-65) — can all be applied to further understanding the knowledge and methods of American Indian sciences. They can also be applied to further understanding participants' relationships to the language(s) of the tribe or tribes of which they are a part. Farb writes, "Language becomes man's shaper of ideas rather than simply his tool for reporting ideas" (235). He continues, "the differences between languages are much more than mere obstacles to communication; they represent basic differences in the 'world view' of the various peoples and in what they understand about their environment" (237). World view when applied to the sciences may be taken to mean paradigm. Farb makes the connection to technology more explicit when writing that language, "is a living system that is a part of the cultural equipment of a group, and it reveals a culture at least as much as do spear points, kinship groups, or political institutions" (239). Clearly, the opportunity to learn more about the participants-to participate with them and to lean their languages - would help researchers to learn more about American Indian sciences.

It is unclear whether this project has grown beyond the capabilities of AIOIC. There are certainly AIOIC students who are willing to participate in this research, and the resources required are meager, primarily support and time. Unfortunately, it may not be 
apparent until the end of the current accreditation period whether students in health occupations are struggling significantly in sciences to make this project again important to AIOIC. With regards to the high-school students who were excluded from the survey, federal, state, local, and institutional barriers impede any improvement in data collection that could be attempted. Nothing can be taught without the willingness to create a location in which to teach it. For now, the larger American Indian Sciences project remains my own. 


\section{Conclusions}

I find a great deal of encouragement from a single response to Question 17, When you hear the word science what kind of people do you imagine doing science (who are scientists) and what do you imagine them doing (what is science)? That response is, "Original teachings of our tribe." In this one response, this one person's perceptions of science, we locate what might be American Indian sciences. But who is this person? What led him or her to respond this way? What did she or he mean? Because of these unanswered questions, I am also discouraged by the opportunities lost by using survey methods.

The survey itself does not show that there are American Indian sciences different from Western sciences. However, in completing the survey and this project, I believe I have been able to define science in a way that need not diminish non-Western cultures or further oppress and colonize. As a pilot project, my American Indian Science Survey shows the inadequacies of survey methods in developing what is needed for the completion of the American Indian Sciences project or improving the teaching of science at AIOIC. However, it points the way toward methods that would allow a greater understanding of American Indians and what might, ultimately, be called their sciences.

I have felt very much out of place at times at AIOIC, so much so that I have found myself comparing my experiences with those of characters from science fiction. Someone traveling on a starship or stepping through a gate to another world would never expect to find a culture without science. Likewise, it is unreasonable to expect that the science 
found there would have developed the same as our own. Unfortunately, what is expected in science fiction is not necessarily expected in our real-world experience.

It isn't necessary to cross the stars, or even an ocean, to be in another world: one's neighbor may live a life significantly different than one's own. In our connected world, the emphasis tends to be on how similar everyone seems to be getting; for this very reason, there is an increased need to preserve cultures, differences, and diversity. I may not be able to cross the stars, but the world I have begun to see gives me just as much wonder and excitement, even more so-because it is real. 


\section{Works Cited}

Baraga, Frederic. A Theoretical and Practical Grammar of the Otchipwe Language for the Use of Missionaries and Other Persons Living Among the Indians. $2^{\text {nd }}$ ed. Motreal: Beauchemin \& Valois, 1878.

Blaisdell, Bob, ed. Great Speeches by Native Americans. Toronto: Dover, 2000.

Cajete, Gregory. Native Science: Natural Laws of Interdependence. Santa Fe: Clear Light Publishers, 2000.

Denzin, Norman K. and Yvonna S. Lincoln, eds. The SAGE Handbook of Qualitative Research. $4^{\text {th }}$ ed. Thousand Oaks, California: Sage, 2011.

Farb, Peter. Man's Rise to Civilization as Shown by the Indians of North America from Primeval Times to the Coming of the Industrial State. New York: E. P. Dutton \& Co, 1968.

Gross, Alan G. "The Origin of Species: Evolutionary Taxonomy as an Example of Rhetoric of Science." The Rhetorical Turn: Invention and Persuasion in the Conduct of Inquiry. Simons, Herbert W. Chicago: University of Chicago Press: 1990

Gross, Alan G. The Rhetoric of Science. Cambridge: Harvard University Press, 1990.

"honk, n.". OED Online. September 2011. Oxford University Press. 10 October 2011 http://www.oed.com/view/Entry/88203?rskey=Uq4L5m\&result=1\&isAdvanced=f alse.

Indian Self-Determination and Education Assistance Act. January 4, 1975.

Uscode.house.gov. 20 Feb.2011. http://uscode.house.gov/uscodegi/fastweb.exe?getdoc+uscview+Code91+32134+ 0++\%28\%29\%20\%20AND \%20\%28\%2825\%29\%20ADJ\%20USC $\% 29 \% 3$ ACIT E\%20AND $\% 20 \% 28 \mathrm{USC} \% 20 \mathrm{w} \% 2 \mathrm{~F} 10 \% 20 \% 28450 \% 29 \% 29 \% 3 \mathrm{ACITE}$.

Keoke, Emory D and Kay M Porterfield. American Indian Contributions to the World: 15,000 Years of Inventions and Innovations. New York: Checkmark Books, 2003.

Kolmeschate, Kees van, ed. Baraga's Ojibwe Dictionary. 15 June 2011 http://home.kpn.nl/cvkolmes/ojibwe/bardict.doc. 
Kuhn, Thomas S. The Structure of Scientific Revolutions. $3^{\text {rd }}$ ed. Chicago: University of Chicago Press, 1996.

Mihesuah, Devon A., ed. Native and Academics: Researching and Writing about American Indians. Lincoln: University of Nebraska Press, 1998.

New Lakota Dictionary Online. 2011 Lakota Language Consortium. 8 March 2011. http://www.lakotadictionary.org/nldo.php.

"organize, v.". OED Online. September 2011. Oxford University Press. 10 October 2011 http://www.oed.com/view/Entry/132456?redirectedFrom=organize.

Rigney, Lester-Irabinna. "Internationalization of an Indigenous Anticolonial Cultural Critique of Research Methodologies: A Guide to Indigenist Research Methodology and Its Principles.” Wicazo Sa Review 14.2 (1999): 109-121.

"science, n.". OED Online. September 2011. Oxford University Press. 10 October 2011 http://www.oed.com/view/Entry/172672? redirectedFrom=science.

"self-, prefix". OED Online. September 2011. Oxford University Press. 10 October 2011 http://www.oed.com/view/Entry/175092?rskey=PO4OIf\&result=2\&isAdvanced= false.

"self-determination, n.". OED Online. September 2011. Oxford University Press. 10 October 2011 http://www.oed.com/view/Entry/175207?redirectedFrom=selfdetermination.

Simons, Herbert W. The Rhetorical Turn: Invention and Persuasion in the Conduct of Inquiry. Chicago: University of Chicago Press: 1990

Smith, Linda T. "On Tricky Ground: Researching the Native in the Age of Uncertainty." The SAGE Handbook of Qualitative Research. $3^{\text {rd }}$ ed. Denzin, Norman K. and Yvonna S. Lincoln, eds. Thousand Oaks, California: Sage, 2005.

United Nations Declaration on the Rights of Indigenous Peoples. September 13, 2007. Un.org. 20 February 2011 http://www.un.org/esa/socdev/unpfii/en/drip.html.

Weatherford, Jack. Native Roots: How the Indians Enriched America. New York: Ballantine Books, 1991.

Williams, John P. An English-Dakota Dictionary. New York: American Tract Society, 1902.

Wolcott, Harry F. Ethnography: A Way of Seeing. Lanham: Altamira Press, 2008. 


\section{Appendices}

\section{Appendix A The Survey Instrument}

The next pages show the four pages of the Institutional Review Board approved survey instrument that makes up the American Indian Science Survey. 


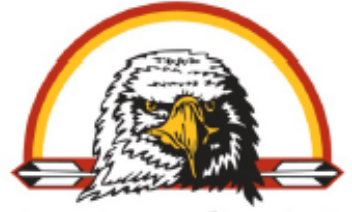

American Indian OIC

\section{American Indian Science Survey}

The purpose of the AIOIC American Indian Science Survey is to provide a record of our students' attitudes and understandings of science, and to document aspects of what we might call American Indian Science from our American Indian students and members of the community.

${ }^{1}$ Please indicate what tribe or tribes you belong to: (please circle any tribe in which you are enrolled and write down the year you were enrolled)

Or check the following box:

$\square$ I do not consider myself a part of any American Indian Tribe from either North or South America.

${ }^{2}$ Please indicate when you were born:

$\square 1990-1992$
$\square 1980-1989$
$\square 1970-1979$
$\square 1960-1969$
$\square 1950-1959$
$\square 1940-1949$
$\square 1930-1939$
$\square 1920-1929$
$\square 1910-1919$
$\square 1900-1909$

${ }^{3}$ Please indicate your gender:

${ }^{4}$ Please indicate where you have lived most of your life (choose one):

$\square$ Twin Cities (inner city)

$\square$ Twin Cities (suburbs)

$\square$ Other cities or large urban areas

$\square$ Small town(s) (pop. 10,000 or less)

$\square$ Rural on a farm or ranch

$\square$ Reservation
${ }^{5}$ Please also indicate the state you have lived in most of your life (choose one):
$\square$ Minnesota
$\square$ North Dakota
$\square$ South Dakota
$\square$ Wisconsin
$\square$ Other:

${ }^{6}$ Please indicate what schooling you have attended up to this point (mark all that apply):

$\square$ Elementary school (Grades K-6)

$\square$ Middle School (7-8)

$\square$ High School (9-12)

$\square$ Job training

$\square$ Technical training

$\square$ Some college (non-degree)

$\square$ College for a 2 year degree

$\square$ College for a 4 year degree

$\square$ Graduate school

${ }^{7}$ Please indicate what schooling you have completed up to this point (mark all that apply):
$\square$ High School Diploma
$\square$ GED
$\square$ Certificate(s) in:

$\square$ Associates Degree(s) in:

$\square$ Bachelor's Degree(s) in:

$\square$ Graduate Degree(s) in:

\section{(The front, exterior, page for all participants)}


This page is meant to record knowledge from our American Indian students and community members.

American Indians have typically learned a great deal from their families and elders. Please mark any skill taught to you in a traditional setting or manner and indicate what relationship you have with the person that taught you (tribal elder, grandmother, grandfather, father, mother, aunt, uncle, community program, etc.).

${ }^{8}$ Please check all that apply:

Please indicate how you are related to the person that taught you:
$\square$ Beading
$\square$ Quillwork
$\square$ Leatherwork/tanning
$\square$ Sewing (traditional methods)
$\square$ Dyeing (using native plants)
$\square$ Fiber use/collection
$\square$ Weaving
$\square$ Fishing (traditional methods)
$\square$ Hunting (traditional methods)
$\square$ Ricing (harvesting/storing)
$\square$ Gardening (traditional methods)
$\square$ Cooking (traditional methods)
$\square$ Preserving (traditional methods)
$\square$ Pottery making (traditional methods)
$\square$ Navigating/using the stars
$\square$ Spirituality/ceremonies
$\square$ Smudging
$\square$ Dancing
$\square$ Singing
$\square$ Drumming
$\square$ Storytelling
$\square$ Healing
$\square$ Language(s)
Please list all:
$\square$ Other:
$\square$ Other:
$\square$ Other:

\section{(The second, interior, page for American Indian participants)}


This page is meant to record knowledge from our American Indian students and community members.

'If you had a problem that you thought would need to be addressed by your tribe(s), what would you do and how would your tribe go about solving it?

${ }^{10}$ If you wanted to learn something about nature that was completely new to you and your people, what would you do?

\footnotetext{
${ }^{11}$ Please indicate when you would try to find written knowledge (books, websites, etc.) when trying to solve a problem or learn something new (choose one):

$\square$ I almost always look for written knowledge first, before talking to anyone

$\square$ I usually look for written knowledge first, before talking to anyone

$\square$ I look for written knowledge equally as often as looking for someone to talk to

$\square$ I usually talk to someone first, before trying to find written knowledge

$\square$ I almost always talk to someone first, before trying to find written knowledge

${ }^{12}$ Please indicate how often you try to find written knowledge (books, websites, etc.) while trying to solve a problem or learn something new (choose one):

$\square$ I am always trying to find written knowledge while learning something new or solving a problem

$\square$ I very often try to find written knowledge while learning something new or solving a problem

$\square$ I sometimes try to find written knowledge while learning something new or solving a problem

$\square$ I occasionally try to find written knowledge while learning something new or solving a problem

$\square$ I almost never try to find written knowledge while learning something new or solving a problem

${ }^{13}$ Please indicate the kind of person you consider going to when trying to solve a problem or learn something new (choose one):

$\square$ I always try to find someone that studied the subject/problem in school

$\square$ I often try to find someone that studied the subject/problem in school

$\square$ I sometimes try to find someone that studied the subject/problem in school

$\square$ I occasionally try to find someone that studied the subject/problem in school

$\square$ I almost never try to find someone that studied the subject/problem in school
}

\section{(The third, interior, page for American Indian participants)}


${ }^{14}$ Please indicate how you feel when you are learning (choose one):

$\square$ I almost always feel good when learning

$\square$ I often feel good when learning

$\square$ I sometimes feel good when learning

$\square$ I occasionally feel good when learning

$\square$ I almost never feel good when learning
${ }^{15}$ Please indicate how you feel when you are reading (choose one):

$\square$ I almost always feel good when reading

$\square$ I often feel good when reading

$\square$ I sometimes feel good when reading

$\square$ I occasionally feel good when reading

$\square$ I almost never feel good when reading

${ }^{16}$ Please indicate how much you know about science compared to the rest of your family (choose one):

$\square$ I think I know more about science than almost everyone in my family

$\square$ I think I know more about science than most of my family

$\square$ I think I know as much about science as everyone else in my family

$\square$ I think I know less about science than most of my family

$\square$ I think I know the least about science compared to the rest of my family

${ }^{17}$ When you hear the word science what kind of people do you imagine doing science (who are scientists) and what do you imagine them doing (what is science)?

${ }^{18}$ Please indicate how you feel about science (choose one):

$\square$ I like science a lot

$\square$ I like science somewhat

$\square$ I do not like or dislike science

$\square$ I dislike science somewhat

$\square$ I dislike science a lot

${ }^{19}$ Is there anything you do that you would consider science? Please try to list everything that you feel applies.

${ }^{20}$ Do you consider yourself a scientist? $\square$ yes $\square$ no why or why not?

${ }^{21}$ Please indicate: $\square$ I am currently a student of AIOIC $\square$ I am currently not a student of AIOIC

${ }^{22}$ Please also indicate when and where you have taken this survey before:

Or check the following box: $\square$ I have never taken this survey before

\section{(The fourth, exterior, page for all participants)}




\section{Appendix B Expectations of Results of AISS}

Question 1 Please indicate what tribe or tribes you belong to: (please circle any tribe in which you are enrolled and write down the year you were enrolled) Or check the following box: I do not consider myself a part of any American Indian tribe from either North or South America

That there would be participants that do not consider themselves a part of American Indian tribes, and that there would be students that do. That of the students that do, many but not all would be enrolled. That a few participants would indicate they belong to more than one tribe.

Question 2 Please indicate when you were born

That all participants would check one box indicating the decade of their birth.

Question 3 Please indicate your gender

That most participants would write down something that would indicate their sex (either

male or female), and that a few participants would write down something that would indicate that they are transgendered.

Question 4 Please indicate where you have lived most of your life (choose one)

That each of the six choices presented on the survey instrument would be selected by at least one participant, but that most participants would select the inner city (of the Twin Cities) as where they have lived most of their lives. 
Question 5 Please also indicate the state you have lived in most of your life (choose one) That most participants would select Minnesota as the state they have lived in the most, but that there would be participants that would select other states or even write in a state not listed with a check box.

Question 6 Please indicate what schooling you have attended up to this point (mark all that apply)

That each of the nine choices presented on the survey instrument would be selected by at least one participant.

Question 7 Please indicate what schooling you have completed up to this point (mark all that apply)

That of the choices available, each would be selected by at least one participant. That there would be participants that would indicate completion of high school and participants that indicate completion of a GED that have gone on to obtain advanced degrees (that they write in). That more participants will indicate attending school (Question 6) than completing (Question 7)

Question 8 American Indians have typically learned a great deal from their families and elders. Please mark any skill taught to you in a traditional setting or manner and indicate what relationship you have with the person that taught you (tribal elder, 
grandmother, grandfather, father, mother, aunt, uncle, community program, etc.). Please check all that apply

That of the choices available, each would be selected by at least one participant. That some of the choices will be selected more than others. That the person written in as teaching each choice selected will typically be of the same gender of the person completing the survey instrument.

Question 9 If you had a problem that you thought would need to be addressed by your tribe(s), what would you do and how would your tribe go about solving it That as an open response question, fewer participants will provide an answer to this question. That a few responses will include problem solving methods unique to American Indians.

Question 10 If you wanted to learn something about nature that was compeletely new to you and your people, what would you do

That as an open response question, fewer participants will provide an answer to this question. That a few responses will include methods of learning unique to American Indians.

Question 11 Please indicate when you would try to find written knowledge (books, websites, etc.) when trying to solve a problem or learn something new (choose one); Question 12 Please indicate how often you would try to find written knowledge (books, 
websites, etc.) when trying to solve a problem or learn something new (choose one); Question 13 Please indicate the kind of person you consider going to when trying to solve a problem or learn something new (choose one)

That participants that respond more positively to written knowledge and those with schooling will also respond more positively to reading and their own schooling (Questions 14 \& 15)

Question 14 Please indicate how you feel when you are learning (choose one) That participants that feel good when learning will indicate more knowledge of skills taught to them by their fellow American Indians (Question 8) than participants responding more negatively.

Question 15 Please indicate how you feel when you are reading (choose one) That participants that feel good when reading will indicate more knowledge of skills taught to them by their fellow American Indians (Question 8) than participants responding more negatively.

Question 16 Please indicate how much you know about science compared to the rest of your family (choose one)

That participants that feel they know more about science also respond more positively toward their own learning and reading (Questions $15 \& 16$ ) 
Question 17 When you hear the word science what kind of people do you imagine doing science (who are scientists) and what do you imagine them doing (what is science)

That as an open response question, fewer participants will provide an answer. That participants will describe a stereotype of scientists and what they do.

Question 18 Please indicate how you feel about science (choose one) That participants that like science a lot will indicate more knowledge of skills taught to them by their fellow American Indians (Question 8) than participants responding more negatively.

Question 19 Is there anything you do that you would consider science? Please try to list everything you feel applies.

That as an open response question, fewer participants will provide an answer. That participants that provide a more inclusive description of scientists and what they do (Question 17) will be more likely to consider something that they do science.

Question 20 Do you consider yourself a scientist? Why or why not?

That as an open response question, fewer participants will provide an answer. That participants that like science a lot (Question 18) will be more likely to consider themselves scientists. 
Question 21 Please indicate: I am currently a student of AIOIC; I am currently not a student of AIOIC

That there will be participants that are students of AIOIC and participants that are not.

Question 22 Please also indicate when and where you have taken this survey before. Or check the following box: I have never taken this survey before.

That no one will indicate having taken the survey before.

\section{Appendix C Table of Responses for Question 17}

\begin{tabular}{|l|}
\hline I imagine them changing the world of evolution \\
\hline $\begin{array}{l}\text { Researchers looking systematically for cures or new methods or -Amateurs } \\
\text { trying to solve a problem }\end{array}$ \\
\hline Lab s? - working with bacteria/germs \\
\hline bioscience, astronomy, geology \\
\hline $\begin{array}{l}\text { I really thing of smart people that know about everything scientists are very } \\
\text { smart people that travel around the world learning new things }\end{array}$ \\
\hline older white haired beard looking in microscope, disecting things \\
\hline I imagine many types of people doing a wide variety of things. \\
\hline $\begin{array}{l}\text { People who want to know about cures, I imagine them doing myth busters or } \\
\text { blowing things to pieces. }\end{array}$ \\
\hline Tests labs studies \\
\hline Study of animals, cells and humans \\
\hline Very smart people in they doing experiments \\
\hline studying life and living creatures \\
\hline $\begin{array}{l}\text { smart people, people that like to put stuff together trying to get light bulb } \\
\text { working w/ battery or something }\end{array}$ \\
\hline $\begin{array}{l}\text { explore: exploring in different fields like in medical fields is my interest. } \\
\text { Science is the study of biology and zoology of living things and plants. }\end{array}$ \\
\hline When you say science I think of medicine, technology and things of that sort. \\
\hline finding out new cures for diseases \\
\hline labs, microbiology, make cures, dr \\
\hline the men or women that stucy science in school that have the love for it \\
\hline People working in labs, discovering cures \\
\hline
\end{tabular}


science some to leaond for your good because to day the holl world use science lik everyone dirk a waltier mathmatictions I think this has a lot to do with math

finding cures for diseases, doing the Ag stuff, making bombs to secure the country, botony, geo-thermol

Can't think of any -

everyone can be a science with life is science

I think facts of nature

I love science. I have taken many classes towards a science degree.

Physician, engineers, mathematician, chemist, physicist, etc.

Science is the study of different subjects (earth, body, animals, etc.), I believe anyone is capable of learning science.

Original teachings of our tribe

Working in a lab doing experiment

Chemists, Doctors, IT People

Doctors, continuaously researching information

I think of a smart person, like they mix stuff together ixperiences stuff.

Study of nature, new inventions, study of problems within people (medical). I think people who are scientists or doing something in science have been highly educated and doing what they enjoy.

Chemists, researchers, botanists, biologists, ecologists

Intelligent, curious people, working in a lab, doing experiments, researching cures for disease and working on ways to improve our environment.

Working in a lab. (Lab coat) NASA

Professors, teaching in college sessions

Forensic sciences, (lab work, DNA samples)

Weather People, Doctors, Teachers

I'm a big science fiction fan, I remain very open minded about science $\&$ then it can help us

smart , nerdy people

The people that creat something out of nothing (just imagination) \& some scrap

Studying new ways to help the earth - people as a whole - people who are educated in science or have a love for the scientific stuff

About Albert Einstein

IDK

Building Bombs, Destorying nature, etc.

Lab worker's who work with chemicals and biologist. Study of chemicals

Everyday people with Science Degrees

$\mathrm{N} / \mathrm{A}$

Science has som many classes or titles. But the one I find vey interesting has to 
do with DNA. Mixing, cutting, classifieing different DNA. Creating life. I always imagine they are searching something like living things or mon living things "Science is the learning of living thing and non-living things.

I think space, planets, men in white jackets with this glasses

Archiologist

Albert Einstien, Nichole Tesla

Earth

(person in lab) working on forensic stuff.

Doctors, pharmacis, nursing staff

people in lab coats using microscopes "n" stuff

Finding something that hasn't been discovered

A time before I though of scientists of the fields of science being more of a elderly white male dominated field but as time went by where seeing more people of color entering this field - I would like to see more women in this field Science to me is the essence of Life in Universe and Earth, Moon, Stars. It was created by a living creator who I study about in my Highest book of Knowledge, My Bible. I call Him Who made all of it Father God.

I get blank thoughs nothing comes up.

Biologists chemists doctors physiologists Science is the study of plant earth moon stars medicine physiology body

cutting open frogs

wearing white clothes working with cemecil's

I think the word science is a hard word. I find science a tough subject. I know

NASA is a part of science.

I imagine them in white clothes.

I imagine scientist working on issues dealing with nature and our environment

Studying

studying, researching networking, in labs \& doing experiments

Teachers, Biologist, Ecologist

I have to go find someine in school sho know where is Nirml or Lloyd. I like to read the publications in the library ex: discovery $\sim$ I know so little of the natural world. I am looking forward to my nursing classes. I think of "science" class. I have a difficult time even putting any scientific questions on paper. I consider myself learning, however systematically $\sim$ in no specific order I am continually learning (Thanx OIC) Gets me where I want to go.

Dotors

Girls - Science Museum

labs and stuff like that 